OPEN ACCESS

Edited by:

Jun Chen,

Fudan University, China

Reviewed by:

Xiaoli Shen,

Qingdao University Medical

College, China

Hebah Al Khatib,

Qatar University, Qatar

*Correspondence:

Zhi Zeng

zhizeng_scu@yeaah.net

Sheyu Li

lisheyu@gmail.com

Specialty section

This article was submitted to Infectious Diseases - Surveillance,

Prevention and Treatment,

a section of the journa

Frontiers in Medicine

Received: 03 May 2021

Accepted: 29 July 2021

Published: 19 August 2021

Citation:

Li Y, Yang $X$, Yan P, Sun T, Zeng Z and Li S (2021) Metformin in Patients With COVID-19: A Systematic Review and Meta-Analysis. Front. Med. 8:704666. doi: 10.3389/fmed.2021.704666

\section{Metformin in Patients With COVID-19: A Systematic Review and Meta-Analysis}

\author{
Yin $\mathrm{Li}^{1}$, Xue Yang ${ }^{2}$, Peijing Yan ${ }^{2}$, Tong Sun ${ }^{3}$, Zhi Zeng ${ }^{4 *}$ and Sheyu $\mathrm{Li}^{5,6 *}$ \\ 1 "Double First-Class" Construction Office, West China Hospital, Sichuan University, Chengdu, China, ${ }^{2}$ Department of \\ Epidemiology and Biostatistics, West China School of Public Health and West China Fourth Hospital, Sichuan University, \\ Chengdu, China, ${ }^{3}$ Department of Neurosurgery, West China Hospital, Sichuan University, Chengdu, China, ${ }^{4}$ Department of \\ Cardiology, West China Hospital, Sichuan University, Chengdu, China, ${ }^{5}$ Department of Endocrinology and Metabolism, West \\ China Hospital, Sichuan University, Chengdu, China, ${ }^{6}$ Department of Guideline and Rapid Recommendation, Chinese \\ Evidence-Based Medicine Center, Cochrane China Center and MAGIC China Center, West China Hospital, Sichuan \\ University, Chengdu, China
}

Importance/Background: The coronavirus disease (COVID-19) pandemic is a critical public health issue. Evidence has shown that metformin favorably influences COVID-19 outcomes. This study aimed to assess the benefits and risks of metformin in COVID-19 patients.

Methods: We searched the PubMed, Embase, Cochrane Library, and Chinese Biomedical Literature Database from inception to February 18, 2021. Observational studies assessing the association between metformin use and the outcomes of COVID-19 patients were included. The primary outcome was mortality, and the secondary outcomes included intubation, deterioration, and hospitalization. Random-effects weighted models were used to pool the specific effect sizes. Subgroup analyses were conducted by stratifying the meta-analysis by region, diabetic status, the adoption of multivariate model, age, risk of bias, and timing for adding metformin.

Results: We identified 28 studies with 2,910,462 participants. Meta-analysis of 19 studies showed that metformin is associated with 34\% lower COVID-19 mortality [odds ratio (OR), 0.66; 95\% confidence interval $\left.(\mathrm{Cl}), 0.56-0.78 ; I^{2}=67.9 \%\right]$ and $27 \%$ lower hospitalization rate (pooled OR, 0.73; 95\% Cl, 0.53-1.00; $I^{2}=16.8 \%$ ). However, we did not identify any subgroup effects. The meta-analysis did not identify statistically significant association between metformin and intubation and deterioration of COVID-19 (OR, 0.94; 95\% Cl, 0.77-1.16; $l^{2}=0.0 \%$ for intubation and $\mathrm{OR}, 2.04 ;$ 95\% Cl, 0.65-6.34; $R^{2}=79.4 \%$ for deterioration of COVID-19), respectively.

Conclusions: Metformin use among COVID-19 patients was associated with a reduced risk of mortality and hospitalization. Our findings suggest a relative benefit for metformin use in nursing home and hospitalized COVID-19 patients. However, randomized controlled trials are warranted to confirm the association between metformin use and COVID-19 outcomes. 
Study Registration: The study was registered on the PROSPERO on Feb 23, 2021 (CRD42021238722).

Keywords: metformin, COVID-19, mortality, hospitalization, intubation, deterioration

\section{INTRODUCTION}

The novel coronavirus disease (COVID-19), caused by the infection of severe acute respiratory syndrome coronavirus 2 (SARS-CoV-2), is changing the everyday life of human-being globally (1). The overall COVID-19 mortality has reached 5\% worldwide, with $1 / 4$ of patients hospitalized with COVID19 requiring intensive care $(2,3)$. Novel approaches targeting COVID-19 is called in emergency $(4,5)$.

Type 2 diabetes is one of the most prevalent noncommunicable diseases worldwide (6), affecting over 100 million adults in China $(7,8)$. Both elevated and fluctuated glucose levels are leading to the death and complication in people living with type 2 diabetes $(9,10)$. Type 2 diabetes shares common risk factors with COVID-19 fatality including age, sex, and obesity (11), and type 2 diabetes itself is one of the top risk factors for the prognosis of COVID-19 (12). Metformin is one of the most widely used anti-diabetic drugs in the past few decades (13-15). In addition to the effect of lowering blood glucose, metformin protects diabetic people from cardiovascular disease, microvascular complications of diabetes and neoplasm $(16,17)$.

Although a recent large cohort from England (18) and a metaanalyses $(19,20)$ suggested that metformin using was associated with lower mortality of COVID-19 patients, the potential benefits of metformin in patients with COVID-19 remain uncertain. The heterogeneous reporting may be attributed to different study design, health care system, study population and statistical approaches. We, therefore, conducted this systematic review and meta-analysis to explore the impact of metformin use on COVID-19 mortality and other patient-important outcomes across various populations and studies.

\section{METHODS}

\section{Study Registration}

The study was registered on the PROSPERO on Feb 23, 2021 (CRD42021238722).

\section{Search Strategy}

Our study followed the preferred reporting items for systematic reviews and meta-analysis (PRISMA) guidelines (21). The literature search was performed in PubMed, Embase, Cochrane Library, and Chinese Biomedical Literature Database from inception to February 18, 2021. The medical subject headings and keywords searched consisted of "COVID-19," "SARSCoV-2," "coronavirus," and "metformin." The detailed search strategy for PubMed is shown in Supplementary Table 1. The hand-search from the references and citations supplements the relevant literature. We searched the literature using a combination of titles/abstracts and medical subject headings. Studies were included if they: (1) were designed as cohort, cross-sectional, case-control studies; (2) compared the rates of death, risk of intubation, disease deterioration, hospitalization, acute respiratory distress syndrome (ARDS), acidosis, and heart failure in COVID-19 patients with and without using metformin, and (3) reported the effect size including odds ratios (ORs), relative risks (RRs), or hazard ratios (HRs) and their 95\% confidence intervals (CIs). We excluded abstracts, case reports, letters, reviews, meta-analyses, registered clinical trials not yet completed, and studies that were not English publications. Two authors (YL and TS) independently screened the titles and abstracts identified from the aforementioned databases, and then, full-text articles were read to assess eligibility. Divergences were resolved with the help of a third evaluator (ZZ).

\section{Data Extraction}

Data were extracted according to a standardized form and included basic information (i.e., first author name, publication year, region, study design), data on participants (i.e., sample size, age, sex, diabetic status, follow-up duration), and data on outcomes [i.e., death, intubation, admission to intensive care unit (ICU), disease deterioration, length of stay, adverse events]. We contacted the corresponding authors to request any missing or unclear data and excluded the study if data was not supplied. Multivariable-adjusted ORs, RRs, or HRs and their 95\% CIs were extracted from the models with full adjustment for potential confounders if more than one model was established.

\section{Risk of Bias Assessment}

The Newcastle-Ottawa Scale was used to assess the risk of bias in the included studies (22). The risks were estimated using the following three terms: patient selection (4 items), study comparability ( 1 item), and outcome assessment ( 3 items), and the results were divided into three grades according to the total score (good, 7-9; fair, 5-6; poor, 0-4).

\section{Data Syntheses}

By identifying a newly published large-scale study in England, we added an exploratory sensitivity analysis to test the robustness of the results. The following analyses were performed to estimate the association between metformin use and mortality among COVID-19 patients. Heterogeneity was estimated using $I^{2}$ statistics. We used random-effects weighted models to pool the specific effect sizes and their 95\% CIs if $I^{2}$ was $>50 \%$, while the fixed-effects weighted models were used if $I^{2}$ was $\leq 50 \%$. RRs and HRs were regarded as approximates for ORs.

Exploratory subgroup analyses were conducted by stratifying the meta-analysis by region (Europe, Asia, or America), diabetic status (population with or without diabetes), the adoption of multivariate model (adopt or not), age ( $<60$ years, 
TABLE 1 | Characteristics of included studies.

\begin{tabular}{|c|c|c|c|c|c|c|c|c|c|c|}
\hline \multirow[t]{2}{*}{ References } & \multirow[t]{2}{*}{ Country } & \multirow[t]{2}{*}{ Region } & \multirow{2}{*}{$\begin{array}{l}\text { Study } \\
\text { design }\end{array}$} & \multirow{2}{*}{$\begin{array}{l}\text { Sample } \\
\text { sizes } \\
\text { M/C }\end{array}$} & \multicolumn{3}{|c|}{ Population with COVID-19 } & \multirow{2}{*}{$\begin{array}{l}\text { Follow-up } \\
\text { time (day) }\end{array}$} & \multirow[t]{2}{*}{ COVID-19 definition } & \multirow{2}{*}{$\begin{array}{l}\text { Risk of bias } \\
\text { score }\end{array}$} \\
\hline & & & & & $\begin{array}{l}\text { Proportion } \\
\text { f diabetes }\end{array}$ & $\begin{array}{l}\text { Age (year) } \\
\text { mean } \pm S D\end{array}$ & Male $(n, \%)$ & & & \\
\hline $\begin{array}{l}\text { Izzi Engbeaya } \\
\text { et al. (39) }\end{array}$ & UK & Europe & $\begin{array}{l}\text { Retrospective } \\
\text { cohort study }\end{array}$ & $169 / 168$ & 1.00 & $65.8 \pm 17.5$ & $202,60.0 \%$ & 30 & $\begin{array}{l}\text { SARS-CoV-2 swab-positive } \\
\text { (RT-PCR) }\end{array}$ & 5 \\
\hline $\begin{array}{l}\text { Mirsoleymani } \\
\text { et al. (45) }\end{array}$ & Iran & Asia & $\begin{array}{l}\text { Retrospective } \\
\text { cohort study }\end{array}$ & $36 / 69$ & 0.11 & $59.8 \pm 17.2$ & $76,72.5 \%$ & 8 to 25 & Chest CT & 6 \\
\hline Liu et al. (43) & China & Asia & $\begin{array}{l}\text { Retrospective } \\
\text { cohort study }\end{array}$ & $18 / 46$ & 0.33 & $66.0 \pm 3.0$ & $35,54.7 \%$ & NA & $\begin{array}{l}\text { SARS-CoV-2 infection } \\
\text { (RT-PCR) }\end{array}$ & 7 \\
\hline $\begin{array}{l}\text { Jiang et al. } \\
(40)\end{array}$ & China & Asia & $\begin{array}{l}\text { Retrospective } \\
\text { cohort study }\end{array}$ & $100 / 228$ & 1.00 & $66.1 \pm 4.1$ & $174,53.1 \%$ & NA & $\begin{array}{l}\text { WHO interim guidance and } \\
\text { the Diagnosis and Treatment } \\
\text { Protocol for Coronavirus } \\
\text { Pneumonia (trial version 7) } \\
\text { released by National Health } \\
\text { Commission of China }\end{array}$ & 8 \\
\hline $\begin{array}{l}\text { Wang et al. } \\
(28)\end{array}$ & UK & Europe & $\begin{array}{l}\text { Retrospective } \\
\text { cohort study }\end{array}$ & $10183 / 10183$ & 331.00 & $67.5 \pm 12.5$ & $\begin{array}{l}10,623 \\
52.2 \%\end{array}$ & NA & $\begin{array}{l}\text { SARS-CoV-2 swab-positive } \\
\text { (RT-PCR)or positive } \\
\text { anti-body tests }\end{array}$ & 9 \\
\hline $\begin{array}{l}\text { Choi et al. } \\
\text { (35) }\end{array}$ & South Korea & Asia & $\begin{array}{l}\text { Retrospective } \\
\text { cohort study }\end{array}$ & $12 / 281$ & 0.72 & $29.0 \pm 5.0$ & $214,73.0 \%$ & NA & $\begin{array}{l}\text { SARS-CoV-2 (RT-PCR) } \\
\text { nasal and oropharyngeal } \\
\text { swabs-positive }\end{array}$ & 7 \\
\hline Kim et al. (41) & South Korea & Asia & $\begin{array}{l}\text { Retrospectively } \\
\text { observational } \\
\text { study }\end{array}$ & y113/969 & 0.22 & $>18$ & $384,35.5 \%$ & NA & $\begin{array}{l}\text { SARS-CoV-2 (RT-PCR) } \\
\text { nasal and oropharyngeal } \\
\text { swabs-positive }\end{array}$ & 8 \\
\hline $\begin{array}{l}\text { Orioli et al. } \\
(27)\end{array}$ & Belgium & Europe & $\begin{array}{l}\text { Retrospective } \\
\text { study }\end{array}$ & $45 / 23$ & 0.89 & $69.0 \pm 14.0$ & $35,48.0 \%$ & NA & $\begin{array}{l}\text { SARS-CoV-2 (RT-PCR) } \\
\text { nasal and oropharyngeal } \\
\text { swabs-positive }\end{array}$ & 6 \\
\hline Do et al. (38) & South Korea & Asia & $\begin{array}{l}\text { Retrospective } \\
\text { study }\end{array}$ & $469 / 1301$ & 1.00 & 60.7 & $1,056,59.7 \%$ & NA & ICD-10-CM & 8 \\
\hline $\begin{array}{l}\text { Bramante } \\
\text { et al. (24) }\end{array}$ & US & America & $\begin{array}{l}\text { Retrospective } \\
\text { cohort study }\end{array}$ & 2333/3923 & 1.00 & $74.9 \pm 4.2$ & $2,954,47.2 \%$ & NA & $\begin{array}{l}\text { SARS-CoV-2 (RT-PCR), or } \\
\text { manual chart review by } \\
\text { UHG, or reported from thr } \\
\text { hospital to UHG }\end{array}$ & 6 \\
\hline Lally et al. (25) & US & America & $\begin{array}{l}\text { Retrospective } \\
\text { cohort study }\end{array}$ & $127 / 476$ & 0.40 & $75.9 \pm 11.2$ & $586,97.2 \%$ & 30 & SARS-CoV-2 infection & 8 \\
\hline $\begin{array}{l}\text { Cheng et al. } \\
\text { (34) }\end{array}$ & China & Asia & $\begin{array}{l}\text { Retrospective } \\
\text { cohort study }\end{array}$ & 678/535 & 1.00 & $63.3 \pm 3.5$ & $632,52.1 \%$ & NA & NA & 8 \\
\hline Luo et al. (44) & China & Asia & $\begin{array}{l}\text { Retrospective } \\
\text { study }\end{array}$ & 104/179 & 1.00 & $64.3 \pm 3.4$ & $156,55.1 \%$ & NA & $\begin{array}{l}\text { The diagnosis procedures of } \\
\text { COVID-19 were referred to } \\
\text { the Diagnosis and Treatment } \\
\text { of Pneumonia Infected by } \\
\text { Novel Coronavirus issued by } \\
\text { the National Health } \\
\text { Commission of China. }\end{array}$ & 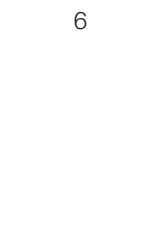 \\
\hline Li et al. (5) & China & Asia & $\begin{array}{l}\text { Retrospective } \\
\text { cohort study }\end{array}$ & $37 / 94$ & 1.00 & $66.8 \pm 11.6$ & $74,56.5 \%$ & 60 & $\begin{array}{l}\text { SARS-CoV-2 (RT-PCR) } \\
\text { nasal and oropharyngeal } \\
\text { swabs-positive }\end{array}$ & 6 \\
\hline $\begin{array}{l}\text { Lalau et al. } \\
\text { (51) }\end{array}$ & France & Europe & $\begin{array}{l}\text { Nationwide } \\
\text { observational } \\
\text { study }\end{array}$ & $1496 / 953$ & 1.00 & $70.9 \pm 12.5$ & $1,568,64.0 \%$ & 28 & $\begin{array}{l}\text { SARS-CoV-2 (RT-PCR) } \\
\text { nasal and oropharyngeal } \\
\text { swabs-positive }\end{array}$ & 6 \\
\hline $\begin{array}{l}\text { Crouse et al. } \\
\text { (36) }\end{array}$ & US & America & $\begin{array}{l}\text { Retrospective } \\
\text { study }\end{array}$ & $76 / 144$ & 1.00 & NA & $272,45.0 \%$ & NA & $\begin{array}{l}\text { SARS-CoV-2 (RT-PCR) } \\
\text { respiratory } \\
\text { specimens-positive }\end{array}$ & 7 \\
\hline $\begin{array}{l}\text { Perez- } \\
\text { Belmonte } \\
\text { et al. (46) }\end{array}$ & Spain & Europe & $\begin{array}{l}\text { Retrospective } \\
\text { cohort study }\end{array}$ & 1618/1048 & 1.00 & $74.9 \pm 8.4$ & $1,647,61.9 \%$ & NA & SARS-CoV-2 (RT-PCR) & 7 \\
\hline
\end{tabular}


TABLE 1 | Continued

\begin{tabular}{|c|c|c|c|c|c|c|c|c|c|c|}
\hline \multirow[t]{2}{*}{ References } & \multirow[t]{2}{*}{ Country } & \multirow[t]{2}{*}{ Region } & \multirow{2}{*}{$\begin{array}{l}\text { Study } \\
\text { design }\end{array}$} & \multirow{2}{*}{$\begin{array}{l}\text { Sample } \\
\text { sizes } \\
\text { M/C }\end{array}$} & \multicolumn{3}{|c|}{ Population with COVID-19 } & \multirow{2}{*}{$\begin{array}{l}\text { Follow-up } \\
\text { time (day) }\end{array}$} & \multirow[t]{2}{*}{ COVID-19 definition } & \multirow{2}{*}{$\begin{array}{l}\text { Risk of bias } \\
\text { score }\end{array}$} \\
\hline & & & & & $\begin{array}{l}\text { Proportion } \\
\text { of diabetes }\end{array}$ & $\begin{array}{l}\text { Age (year) } \\
\text { mean } \pm S D\end{array}$ & Male (n, \%) & & & \\
\hline $\begin{array}{l}\text { Bramante } \\
\text { et al. (30) }\end{array}$ & US & America & $\begin{array}{l}\text { Retrospective } \\
\text { cohort study }\end{array}$ & NA/NA & NA & $46.0 \pm 28.2$ & $2,680,40.0 \%$ & NA & $\begin{array}{l}\text { SARS-CoV-2 } \\
\text { (RT-PCR)-positive }\end{array}$ & 6 \\
\hline $\begin{array}{l}\text { Bramante } \\
\text { et al. (32) }\end{array}$ & US & America & $\begin{array}{l}\text { Retrospective } \\
\text { cohort study }\end{array}$ & 2333/3923 & 1.00 & $70.0 \pm 16.3$ & $2,954,47.2 \%$ & 90 & $\begin{array}{l}\text { SARS-CoV-2 (RT-PCR), or } \\
\text { manual chart review by } \\
\text { UHG, or reported from the } \\
\text { hospital to UHG }\end{array}$ & 8 \\
\hline $\begin{array}{l}\text { Bramante } \\
\text { et al. (24) }\end{array}$ & US & America & $\begin{array}{l}\text { Retrospective } \\
\text { cohort study }\end{array}$ & 676/8879 & 0.205 & $55.0 \pm 16.8$ & $4,519,47.3 \%$ & NA & $\begin{array}{l}\text { SARS-CoV-2 (RT-PCR) } \\
\text {-positive }\end{array}$ & 8 \\
\hline $\begin{array}{l}\text { Cariou et al. } \\
\text { (33) }\end{array}$ & France & Europe & $\begin{array}{l}\text { Retrospective } \\
\text { study }\end{array}$ & $746 / 571$ & 0.885 & $69.8 \pm 13.0$ & $855,64.9 \%$ & NA & $\begin{array}{l}\text { SARS-CoV-2 (RT-PCR) } \\
\text {-positive and/or } \\
\text { clinically/radiologically (i.e., } \\
\text { as ground-glass opacity } \\
\text { and/or crazy paving on } \\
\text { chest computed } \\
\text { tomography [CT] scan) }\end{array}$ & 4 \\
\hline $\begin{array}{l}\text { Nafakhi et al. } \\
(26)\end{array}$ & Iraq & Asia & $\begin{array}{l}\text { Retrospective } \\
\text { observational } \\
\text { study }\end{array}$ & $35 / 157$ & 0.349 & $50.2 \pm 15.7$ & $91,47.4 \%$ & NA & $\begin{array}{l}\text { SARS-CoV-2 (RT-PCR) } \\
\text { nasopharyngeal } \\
\text { swabs-positive }\end{array}$ & 8 \\
\hline $\begin{array}{l}\text { Yitao et al. } \\
(48)\end{array}$ & China & Asia & $\begin{array}{l}\text { Retrospective } \\
\text { cohort study }\end{array}$ & $9 / 248$ & 0.058 & $46.0 \pm 17.0$ & $140,54.0 \%$ & 20 & $\begin{array}{l}\text { SARS-CoV-2 (RT-PCR) } \\
\text { nasopharyngeal } \\
\text { swabs-positive }\end{array}$ & 6 \\
\hline $\begin{array}{l}\text { Al Hayek } \\
\text { et al. (29) }\end{array}$ & Saudi Arabia & Asia & $\begin{array}{l}\text { Retrospective } \\
\text { study }\end{array}$ & 700/106 & 1.00 & $57.6 \pm 13.9$ & $441,54.7 \%$ & NA & $\begin{array}{l}\text { SARS-CoV-2 (RT-PCR) } \\
\text { nasopharyngeal } \\
\text { swabs-positive }\end{array}$ & 7 \\
\hline $\begin{array}{l}\text { Zhang et al. } \\
\text { (49) }\end{array}$ & China & Asia & $\begin{array}{l}\text { Retrospective } \\
\text { cohort study }\end{array}$ & $15 / 37$ & 1.00 & $65.5 \pm 8.70$ & $33,63.5 \%$ & $>60$ & $\begin{array}{l}\text { SARS-CoV-2 (RT-PCR) } \\
\text { nasopharyngeal } \\
\text { swabs-positive }\end{array}$ & 5 \\
\hline Gao et al. (38) & China & Asia & $\begin{array}{l}\text { Case-control } \\
\text { study }\end{array}$ & $56 / 54$ & 1.00 & $67.9 \pm 5.2$ & $46,41.8 \%$ & NA & $\begin{array}{l}\text { Guidelines on the Diagnosis } \\
\text { and Treatment of } \\
\text { Pneumonia Infected by } \\
\text { Novel Coronavirus issued by } \\
\text { the National Health } \\
\text { Commission of China }\end{array}$ & 8 \\
\hline $\begin{array}{l}\text { Wang et al. } \\
(47)\end{array}$ & US & America & $\begin{array}{l}\text { Retrospective } \\
\text { cohort study }\end{array}$ & $9 / 49$ & 0.28 & $67 \pm 12.5$ & $30,52.0 \%$ & NA & $\begin{array}{l}\text { SARS-CoV-2 (RT-PCR) } \\
\text { nasopharyngeal } \\
\text { swabs-positive }\end{array}$ & 6 \\
\hline $\begin{array}{l}\text { Khunti et al. } \\
\text { (18) }\end{array}$ & UK & Europe & Cohort study & $\begin{array}{c}1800005 / 28 \\
465\end{array}$ & 28511.00 & $67(57-77)$ & $\begin{array}{c}1593730 \\
55.9 \%\end{array}$ & NA & $\begin{array}{l}\text { Deaths were defined as } \\
\text { COVID-19 related if the } \\
\text { ICD-10 codes U07.1 } \\
\text { (COVID-19, virus identified) } \\
\text { or U07.2 (COVID-19, virus } \\
\text { not identified) were } \\
\text { recorded. }\end{array}$ & 9 \\
\hline
\end{tabular}

M, metformin group; C, control group; ICD, International Classification of Diseases; SD, standard deviation; NA, not available.

$\geq 60$ years, or not available), risk of bias (poor, fair, and good), and timing for metformin administration (before and after the diagnosis of COVID-19). We applied visual funnel plots, Egger's tests, and Begg's tests to assess for potential publication bias (23). In addition, we conducted a sensitivity analysis by excluding the study with the largest number of sample size and an influencing analysis by successively excluding one study at a time to evaluate whether the result was robust. All statistical analyses were conducted using Stata 15.0 Software (StataCorp., College Station, TX, USA), and two-tailed $P$-values $<0.05$ were considered to be statistically significant.

\section{RESULTS}

\section{Study Selection and Characteristics}

We identified 294 articles during the literature search and one by hand-search, and included 19 studies with 2,903,435 patients 


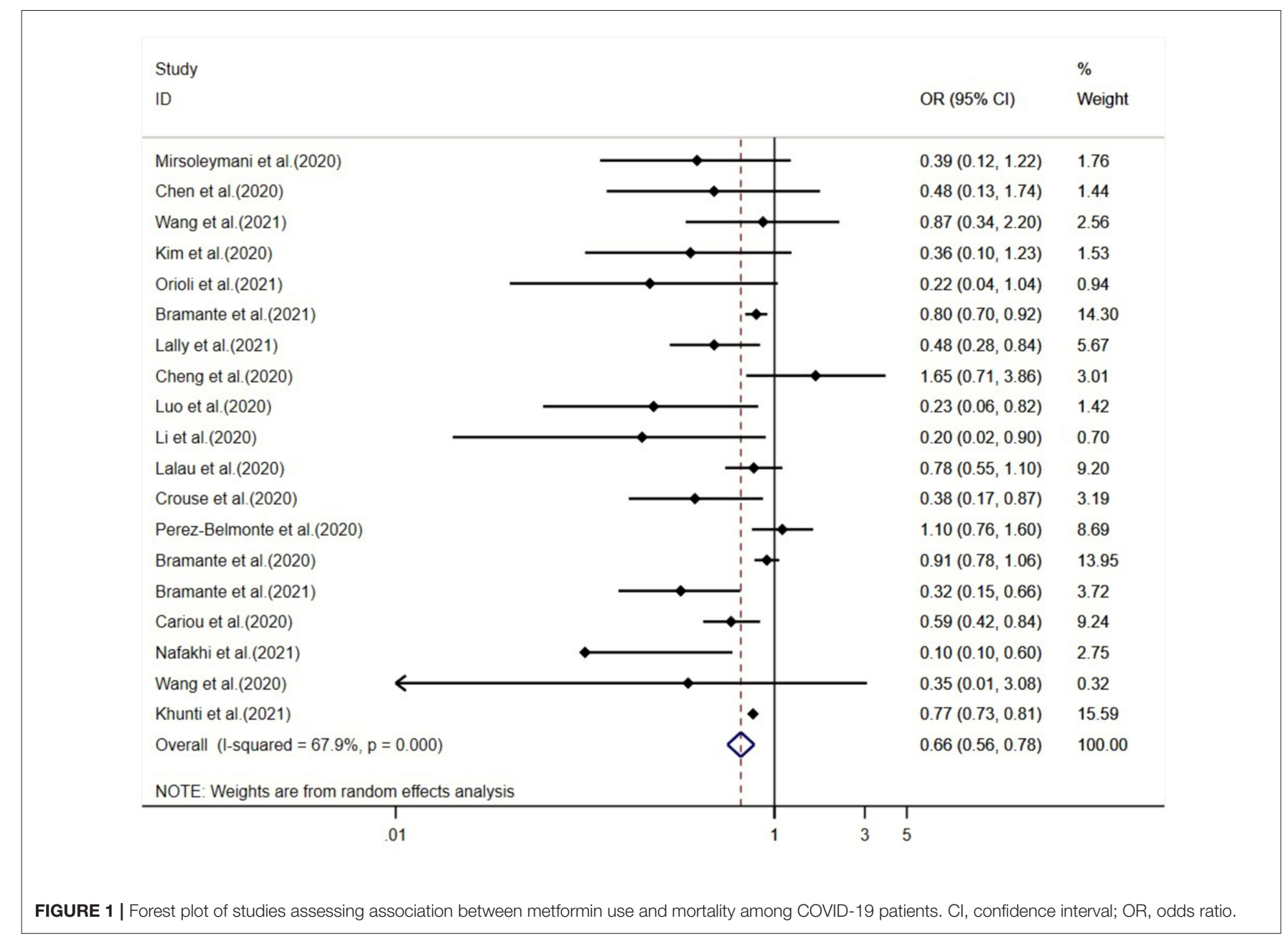

for the meta-analysis of the association between metformin use and risk of mortality (Supplementary Figure 1) (24-50). The characteristics of the included studies are presented in Table $\mathbf{1}$ and Supplementary Table 2. Of these 28 studies, two were preprint studies. Seven of the 28 included studies were conducted in America; 14, Asia; and 7, Europe. According to the quality assessment criteria, 16 studies were of good quality; 11, fair quality; and 1 study, poor quality (Supplementary Table 3).

\section{Metformin Use and COVID-19 Mortality}

The meta-analysis suggested that the use of metformin is associated with $34 \%$ lowered overall mortality (95\% CI, $0.56-0.78 ; I^{2}=67.9 \%$ ) for COVID-19 patients (Figure 1). In sensitivity analysis by leaving the largest study out, the effect size shows robustness (OR, 0.60; 95\% CI, 0.47-0.75; $I^{2}=69.7 \%$ ) (Supplementary Figure 5). The subgroup analyses did not identify any credible subgroup effects (Figure 2). In addition, the influencing analysis by successively excluding one study at a time did not change the findings (Supplementary Figure 6). We did not identify significant publication bias. The funnel plot showed an approximate symmetric distribution, and the $P$-values for Egger's test and Begg's test were 0.879 and 0.270 , respectively (Supplementary Figure 7).

\section{Metformin Use and Other COVID-19 Outcomes}

To examine the association between metformin use and other outcomes, we conducted a further meta-analyses of two $(33,52)$, five $(35,38,39,41,48,49)$, and four $(29-31,47)$ studies estimating the association between metformin use and risk of intubation, deterioration, and hospitalization. The pooled ORs of metformin use with intubation, deterioration, and hospitalization were 0.94 (95\% CI, 0.77-1.16; $\left.I^{2}=0.0 \%\right), 2.04$ (95\% CI, 0.65-6.34; $I^{2}=$ $79.4 \%$ ), and 0.73 (95\% CI, $\left.0.53-1.00 ; I^{2}=16.8 \%\right)$, respectively (Supplementary Figures 2-4).

In addition, it was also reported that metformin use was associated with an $82 \%$ decreased risk of ARDS (OR, 0.18; 95\% CI, 0.05-0.62) (40), a 2.73-fold increased risk of acidosis (HR, 2.73; 95\% CI, 1.04-7.13), and 41\% decreased risk of heart failure (HR, 0.59, 95\%, 0.41-0.83) (34). However, Cheng et al. did not find a significant association between metformin consumption and the risk of incident ARDS with a larger sample size (HR, 0.85; 95\% CI, 0.61-1.17) (34). 


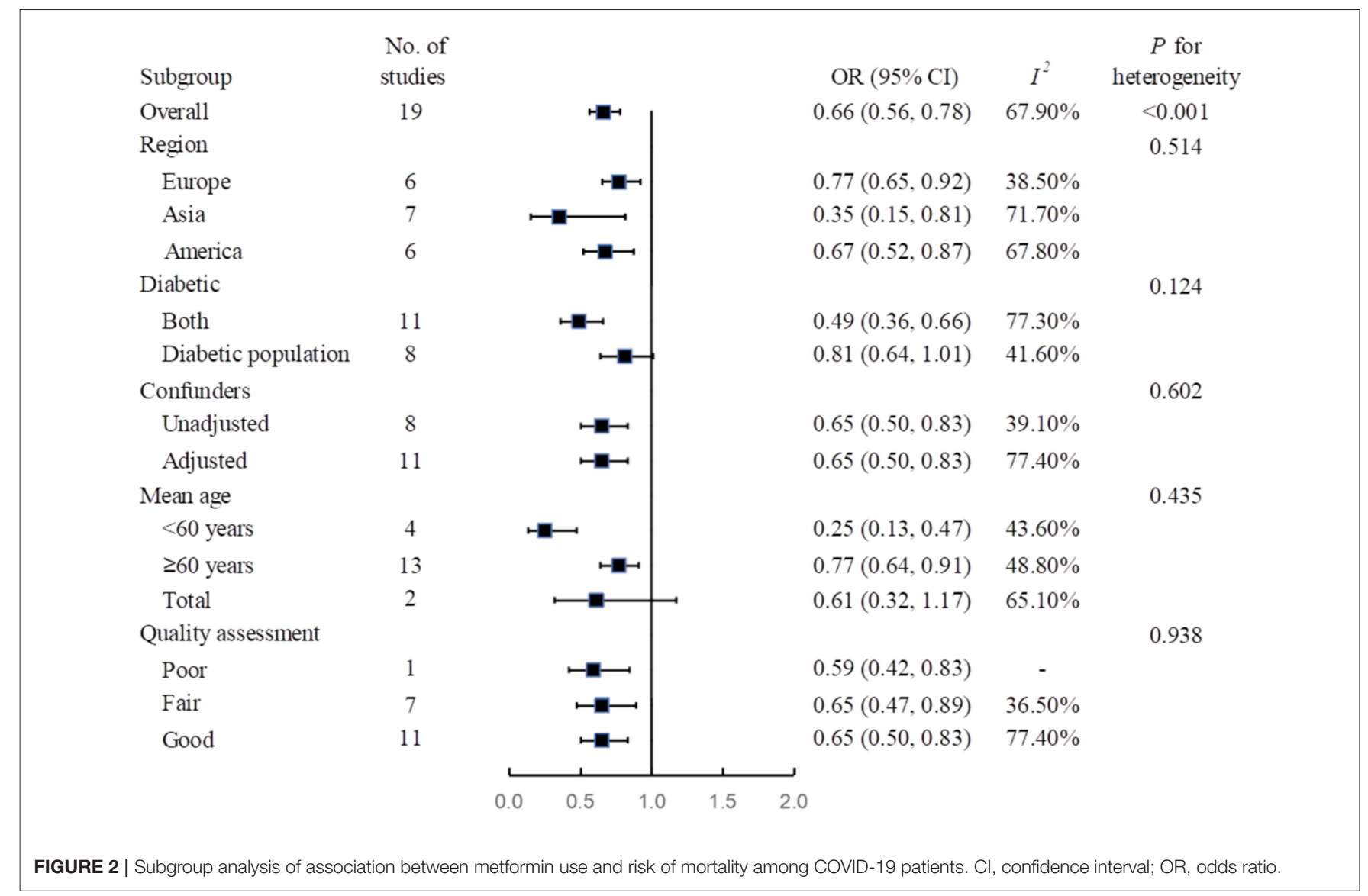

The associations between metformin use and acute kidney injury, acute heart injury, and incident disseminated intravascular coagulation were also examined in this same study; however, the results were still showed no statistical significance. Moreover, metformin use did not affect the risk of in-hospital complications (46). No positive associations between metformin use and the length of ICU and hospital stays were observed in populations in Iraq with COVID19 (26). Choi et al. reported that metformin use was associated with progression-free survival with an HR of 6.196 (95\% CI, 2.58-14.91) among the Korean COVID-19 population, based on a retrospective cohort study (35), while another Korean retrospective study did not find a significant association between metformin use and COVID-19 survival (37).

\section{DISCUSSION}

Our systematic review and meta-analysis showed a strong association between metformin usage and reduced risk of death and hospitalization among COVID-19 patients with diabetes. This is the largest systematic review and meta-analysis on the protective effects of metformin in patients with COVID-19. Different sensitivity analyses confirmed the robustness of the results.
Metformin has been used in people with type 2 diabetes for more than half a century, proving its safety. Metformin is free of severe adverse events except for a low incidence of hyperlactacidemia in patients with advanced kidney diseases (52). Gastrointestinal adverse events are the most short-term concern for metformin affecting approximately $10 \%$ of its users $(50,53)$. Vitamin B12 deficiency is a potential long-term risk in metformin users, but its clinical relevance has not yet been proven $(54,55)$. People may choose once-daily long-acting metformin instead of metformin immediate release if they are hesitating in taking drug more than once per day (56). Reducing over $1 / 3$ death with benefits for other health events found in the current study, the tradeoff of metformin for people with COVID-19 is clear.

Our study is in line with a recent meta-analysis including nine observational studies with 10,233 people (19), but included more people and provided information of additional outcomes. A letter to the editor also supported our findings, which reported a significant decrease in mortality with preadmission metformin use in patients with COVID-19 and diabetes (pooled OR $=0.62$; 95\% CI: 0.43-0.89) (20).

Mechanisms underlying the association between metformin and death and other adverse outcomes remain unclear. Recent studies demonstrated that SARS-CoV-2 uses the SARS$\mathrm{CoV}$ receptor ACE2 for entry and the serine protease TMPRSS2 for $S$ protein priming (57). The expression and 
stability of ACE2 is mediated by AMPK (58), which is considered as the key molecular target of metformin (59). The immunological response induced by SARS-CoV-2 infection mobilizes cytokines, mainly proinflammatory cytokines, and links to the prognosis of COVID-19 (60). Metformin reduces TNF- $\alpha$ to some extent in both human and animal studies $(61,62)$. TNF- $\alpha$ inhibitors are also reported to be associated with a decrease in mortality despite significant findings in a limited model (24). Thus, this pathway might partly explain the association between metformin use and mortality in COVID-19 patients.

There are some limitations that need to be noted when interpreting the results in the practice. First, the dose of metformin, strain of the virus, and the duration of metformin consumption may contribute to the heterogeneity but unavailable to be studied in this study-level analysis. Individual-level data may help explore the factors that contributes to the protective effects of metformin. Second, we did not identify any randomized trials in the systematic review and we are unable to conclude any causation of the results. The effect of metformin needs to be validated through randomized trials. Last, our study identified clear knowledge gap for outcomes of intubation and disease deterioration when current evidences are unable to support clinical interpretation. We call for further studies and analyses investigating metformin use and these two patient-important outcomes.

\section{CONCLUSION}

In conclusion, metformin use was associated with reduced mortality and hospitalization in COVID-19 patients. The findings of our study indicated a relative benefit of metformin use in both nursing home residents and hospitalized patients with COVID-19. However, randomized controlled trials are warranted

\section{REFERENCES}

1. COVID-19 Coronavirus Pandemic. Available online at: https://www. worldometers.info/coronavirus/?utm_campaign=homeAdvegas1? (accessed April 10, 2021).

2. Guan W-J, Ni Z-Y, Hu Y, Liang W-H, Ou C-Q, He J-X, et al. Clinical characteristics of coronavirus disease 2019 in China. N Engl J Med. (2020) 382:1708-20. doi: 10.1056/NEJMoa2002032

3. Zhu J, Zhong Z, Ji P, Li H, Li B, Pang J, et al. Clinicopathological characteristics of 8697 patients with COVID-19 in China: a meta-analysis. Fam Med Community Health. (2020) 8:e000406. doi: 10.1136/fmch-2020-000406

4. Kichloo A, Albosta M, Dettloff K, Wani F, El-Amir Z, Singh J, et al. Telemedicine, the current COVID-19 pandemic and the future: a narrative review and perspectives moving forward in the USA. Fam Med Community Health. (2020) 8:e000530. doi: 10.1136/fmch-2020-000530

5. Li S, Zong Z, Sun, Li XW. New evidence-based clinical practice guideline timely supports hospital infection control of coronavirus disease 2019. Precis Clin Med. (2020) 3:1-2. doi: 10.1093/pcmedi/pbaa008

6. Wang L, Gao P, Zhang M, Huang Z, Zhang D, Deng Q, et al. Prevalence ethnic pattern of diabetes prediabetes in China in 2013. JAMA. (2017) 317:2515-23. doi: 10.1001/jama.2017.7596 to confirm the association between metformin use and outcomes in COVID-19 patients.

\section{DATA AVAILABILITY STATEMENT}

The original contributions presented in the study are included in the article/Supplementary Material, further inquiries can be directed to the corresponding author/s.

\section{AUTHOR CONTRIBUTIONS}

YL, ZZ, and SL: conception or design. YL, XY, PY, and TS: acquisition, analysis, or interpretation. YL, XY, PY, TS, ZZ, and SL: drafting the work or revision and final approval of the manuscript. All authors contributed to the article and approved the submitted version.

\section{FUNDING}

This study was supported by Sichuan Science and Technology Department of Sichuan Provincial Science and Technology Support Project; Optimization Models and Policies Research On Evaluation Of Scientific Research For Clinical Specialties In Research-Oriented Hospitals In China - Taking Hospital H As an Example (2021JDR0283); and 1.3.5 Project for Disciplines of Excellence, West China Hospital, Sichuan University (grant numbers ZYGD18022 and 2020HXF011). The funder had no role in study design, data collection and analysis, decision to publish, or preparation of the manuscript.

\section{SUPPLEMENTARY MATERIAL}

The Supplementary Material for this article can be found online at: https://www.frontiersin.org/articles/10.3389/fmed. 2021.704666/full\#supplementary-material

7. Global Burden of Disease Cancer C, Fitzmaurice C, Abate D, Abbasi N, Abbastabar H, Abd-Allah F, et al. Global, regional, and national cancer incidence, mortality, years of life lost, years lived with disability, and disabilityadjusted life-years for 29 cancer groups, 1990 to 2017: a systematic analysis for the global burden of disease study. JAMA Oncol. (2019) 5:1749-68. doi: 10.1001/jamaoncol.2019.2996

8. Zhou Y, Zhang Y, Zhang R, Zhou Y, Li N, Wang M, et al. Population diversity of cardiovascular outcome trials and real-world patients with diabetes in a Chinese tertiary hospital. Chin Med J. (2021) 134:1317-23. doi: 10.1097/CM9.0000000000001407

9. Clark A, Jit M, Warren-Gash C, Guthrie B, Wang HHX, Mercer SW, et al. Global, regional, and national estimates of the population at increased risk of severe COVID-19 due to underlying health conditions in 2020: a modelling study. Lancet Global Health. (2020) 8:e1003-17. doi: 10.1016/S2214-109X(20)30264-3

10. Li S, Nemeth I, Donnelly L, Hapca S, Zhou, Pearson KER. Visit-to-visit $\mathrm{HbAlc}$ variability is associated with cardiovascular disease and microvascular complications in patients with newly diagnosed type 2 diabetes. Diabetes Care. (2020) 43:426. doi: 10.2337/dc19-0823

11. Simonnet A, Chetboun M, Poissy J, Raverdy V, Noulette J, Duhamel A, et al. High prevalence of obesity in severe acute respiratory syndrome 
coronavirus-2 (SARS-CoV-2) requiring invasive mechanical ventilation. Obesity. (2020) 28:1195-9. doi: 10.1002/oby.22831

12. Huang I, Lim, Pranata MAR. Diabetes mellitus is associated with increased mortality and severity of disease in COVID-19 pneumonia - a systematic review, meta-analysis, and meta-regression. Diabetes Metab Syndr. (2020) 14:395-403. doi: 10.1016/j.dsx.2020.04.018

13. Palmer S, Tendal B, Mustafa R, Vandvik P, Li S, Hao Q, et al. Sodium-glucose cotransporter protein-2 (SGLT-2) inhibitors and glucagon-like peptide-1 (GLP-1) receptor agonists for type 2 diabetes: systematic review and network meta-analysis of randomised controlled trials. BMJ. (2021) 372:m4573. doi: 10.1136/bmj.m4573

14. Garber A, Handelsman Y, Grunberger G, Einhorn D, Abrahamson M, Barzilay J, et al. Consensus statement by the American association of clinical endocrinologists and American college of endocrinology on the comprehensive ttype 2 diabetes management algorithm - 2020 executive summary. Endocr Pract. (2020) 26:107-39. doi: 10.4158/cs-2019-0472

15. Buse J, Wexler D, Tsapas A, Rossing P, Mingrone G, Mathieu C, et al. 2019 update to: management of hyperglycemia in type 2 diabetes, 2018. a consensus report by the American diabetes association (ADA) and the European association for the study of diabetes (EASD). Diabetes Care. (2020) 43: 487-93. doi: 10.2337/dci19-0066

16. Griffin SJ, Leaver JK, Irving GJ. Impact of metformin on cardiovascular disease: a meta-analysis of randomised trials among people with type 2 diabetes. Diabetologia. (2017) 60:1620-9. doi: 10.1007/s00125-017-4337-9

17. Petrie JR, Rossing PR, Campbell IW. Metformin, and cardiorenal outcomes in diabetes: a reappraisal. Diabetes Obes Metab. (2020) 22:904-15. doi: $10.1111 /$ dom. 13984

18. Khunti K, Knighton P, Zaccardi F, Bakhai C, Barron E, Holman N, et al. Prescription of glucose-lowering therapies and risk of COVID-19 mortality in people with type 2 diabetes: a nationwide observational study in England. Lancet Diabetes Endocrinol. (2021) 9:293-303. doi: 10.1016/S2213-8587(21)00050-4

19. Lukito AA, Pranata R, Henrina J, Lim MA, Lawrensia S, Suastika K. The effect of metformin consumption on mortality in hospitalized COVID-19 patients: a systematic review and meta-analysis. Diabetes Metab Syndr. (2020) 14:2177-83. doi: 10.1016/j.dsx.2020.11.006

20. Kow CS, Hasan SS. Mortality risk with preadmission metformin use in patients with COVID-19 and diabetes: a meta-analysis. J Med Virol. (2021) 93:695-7. doi: 10.1002/jmv.26498

21. Moher D, Liberati A, Tetzlaff J, Altman D. Preferred reporting items for systematic reviews and meta-analyses: the PRISMA statement. PLoS Med. (2009) 6:e1000097. doi: 10.1371/journal.pmed.1000097

22. Stang, A. Critical evaluation of the Newcastle-Ottawa scale for the assessment of the quality of nonrandomized studies in meta-analyses. Eur J Epidemiol. (2010) 25:603-5. doi: 10.1007/s10654-010-9491-Z

23. Yang X, Tao S, Peng J, Zhao J, Li S, Wu N, et al. High-sensitivity C-reactive protein and risk of type 2 diabetes: a nationwide cohort study and updated meta-analysis. Diabetes Metab Res Rev. (2021). doi: 10.1002/dmrr.3446. [Epub ahead of print].

24. Bramante CT, Ingraham NE, Murray TA, Marmor S, Hovertsen S, Gronski J, et al. Metformin and risk of mortality in patients hospitalised with COVID19: a retrospective cohort analysis. Lancet Healthy Longev. (2021) 2:e34-41. doi: 10.1016/S2666-7568(20)30033-7

25. Lally MA, Tsoukas P, Halladay CW, O’Neill E, Gravenstein S, Rudolph JL. Metformin is associated with decreased 30-day mortality among nursing home residents infected with SARS-CoV2. J Am Med Dir Assoc. (2021) 22:193-8. doi: 10.1016/j.jamda.2020.10.031

26. Nafakhi H, Alareedh M, Al-Buthabhak K, Shaghee F, Nafakhi A, Kasim S. Predictors of adverse in-hospital outcome and recovery in patients with diabetes mellitus and COVID-19 pneumonia in Iraq. Diabetes Metab Syndr. (2021) 15:33-8. doi: 10.1016/j.dsx.2020.12.014

27. Orioli L, Servais T, Belkhir L, Laterre PF, Thissen JP, Vandeleene B, et al. Clinical characteristics and short-term prognosis of in-patients with diabetes and COVID-19: a retrospective study from an academic center in Belgium. Diabetes Metab Syndr. (2021) 15:149-57. doi: 10.1016/j.dsx.2020. 12.020

28. Wang J, Cooper JM, Gokhale K, Acosta-Mena D, Dhalla S, Byne N, et al. Association of metformin with susceptibility to COVID-19 in people with type 2 diabetes. J Clin Endocrinol Metab. (2021) 106:dgab067. doi: 10.1210/clinem/dgab067

29. Al Hayek AA, Robert AA, Bin Matar A, Algarni A, Alkubedan H, Alharbi $\mathrm{T}$, et al. Risk factors for hospital admission among COVID-19 patients with diabetes a study from Saudi Arabia. Saudi Med J. (2020) 41:1090-7. doi: $10.15537 / \mathrm{smj} .2020 .10 .25419$

30. Bramante C, Tignanelli CJ, Dutta N, Jones E, Tamariz L, Clark JM, et al. Non-alcoholic fatty liver disease (NAFLD) and risk of hospitalization for COVID-19. medRxiv [Preprint]. (2020). doi: 10.1101/2020.09.01.201 85850

31. Bramante CT, Buse J, Tamaritz L, Palacio A, Cohen K, Vojta D, et al. Outpatient metformin use is associated with reduced severity of COVID-19 disease in adults with overweight or obesity. J Med Virol. (2021) 93:4273-9. doi: 10.1002/jmv.26873

32. Bramante CT, Ingraham NE, Murray TA, Marmor S, Hovertsen S, Gronski J, et al. Observational study of metformin and risk of mortality in patients hospitalized with COVID-19. medRxiv [Preprint]. (2020). doi: 10.1101/2020.06.19.20135095

33. Cariou B, Hadjadj S, Wargny M, Pichelin M, Al-Salameh A, Allix I, et al. Phenotypic characteristics and prognosis of inpatients with COVID19 and diabetes: the CORONADO study. Diabetologia. (2020) 63:1500-15. doi: 10.1007/s00125-020-05180-X

34. Cheng X, Liu YM, Zhang X, Lei F, Qin JJ, Chen Z, et al. Metformin is associated with higher incidence of acidosis, but not mortality, in individuals with COVID-19 and pre-existing type 2 diabetes. Cell Metab. (2020) 32:537-7. doi: 10.1016/j.cmet.2020.08.013

35. Choi MH, Ahn H, Ryu HS, Kim BJ, Jang J, Jung M, et al. Clinical characteristics and disease progression in early-stage COVID-19 patients in South Korea. $J$ Clin Med. (2020) 9:1-19. doi: 10.3390/jcm9061959

36. Crouse AB, Grimes T, Li P, Might M, Ovalle F, Shalev A. Metformin use is associated with reduced mortality in a diverse population with COVID-19 and diabetes. Front Endocrinol. (2020) 11:600439. doi: 10.3389/fendo.2020.6 00439

37. Do JY, Kim SW, Park JW, Cho KH, Kang SH. Is there an association between metformin use and clinical outcomes in diabetes patients with COVID-19? Diabetes Metab. (2020). doi: 10.1016/j.diabet.2020.10.006. [Epub ahead of print].

38. Gao Y, Liu T, Zhong W, Liu R, Zhou H, Huang W, et al. Risk of metformin in patients with type 2 diabetes with COVID-19: a preliminary retrospective report. Clin Transl Sci. (2020) 13:1055-9. doi: 10.1111/cts.12897

39. Izzi-Engbeaya C, Distaso W, Amin A, Yang W, Idowu O, Kenkre JS, et al. Adverse outcomes in COVID-19 and diabetes: a retrospective cohort study from three London teaching hospitals. BMJ Open Diabetes Res Care. (2021) 9:e001858. doi: 10.1136/bmjdrc-2020-001858

40. Jiang N, Chen Z, Yin X, Liu L, Yang H, Tan X, et al. Association of metformin with mortality or ARDS in patients with COVID-19 and type 2 diabetes: a retrospective cohort study. Diabetes Res Clin Pract. (2021) 173:108619. doi: 10.1016/j.diabres.2020.108619

41. Kim MK, Jeon JH, Moon JS, Cho NH, Han E, You JH, et al. The clinical characteristics and outcomes of patients with moderate-to-severe coronavirus disease 2019 infection and diabetes in daegu, South Korea. Diabetes Metab J. (2020) 44:602-13. doi: 10.4093/dmj.2020.0146

42. Li J, Wei Q, Li WX, McCowen KC, Xiong W, Liu J, et al. Metformin use in diabetes prior to hospitalization: effects on mortality in COVID-19. Endocr Pract. (2020) 26:1166-72. doi: 10.4158/EP-2020-0466

43. Liu Z, Bai X, Han X, Jiang W, Qiu L, Chen S, et al. The association of diabetes and the prognosis of COVID-19 patients: a retrospective study. Diabetes Res Clin Pract. (2020) 169:108386. doi: 10.1016/j.diabres.2020.108386

44. Luo P, Qiu L, Liu Y, Liu XL, Zheng JL, Xue HY, et al. Metformin treatment was associated with decreased mortality in COVID-19 patients with diabetes in a retrospective analysis. Am J Trop Med Hyg. (2020) 103:69-72. doi: 10.4269/ajtmh.20-0375

45. Mirsoleymani S, Nekooghadam SM, Marzaleh MA, Peyravi M, Soltani A, Sharififar S, et al. Assessment of risk factors for severe coronavirus disease 2019 among Iranian patients. Iran Red Crescent Med J. (2020) 22:e72. doi: 10.32592/ircmj.2020.22.9.72

46. Perez-Belmonte LM, Torres-Pena JD, Lopez-Carmona MD, Ayala-Gutierrez MM, Fuentes-Jimenez F, Huerta LJ, et al. Mortality and other adverse 
outcomes in patients with type 2 diabetes mellitus admitted for COVID-19 in association with glucose-lowering drugs: a nationwide cohort study. BMC Med. (2020) 18:359. doi: 10.1186/s12916-020-01832-2

47. Wang B, Van Oekelen O, Mouhieddine TH, Del Valle DM, Richter J, Cho HJ, et al. A tertiary center experience of multiple myeloma patients with COVID19: lessons learned and the path forward. J Hematol Oncol. (2020) 13:94. doi: 10.1186/s13045-020-00934-x

48. Yitao Z, Mu C, Ling Z, Shiyao C, Jiaojie X, Zhichong C, et al. Predictors of clinical deterioration in non-severe patients with COVID19: a retrospective cohort study. Curr Med Res Opin. (2021) 37:1-14. doi: 10.1080/03007995.2021.1876005

49. Zhang N, Wang C, Zhu F, Mao H, Bai P, Chen LL, et al. Risk factors for poor outcomes of diabetes patients with COVID-19: a single-center, retrospective study in early outbreak in China. Front Endocrinol. (2020) 11:571037. doi: 10.3389/fendo.2020.571037

50. Bonnet F, Scheen A. Understanding, and overcoming metformin gastrointestinal intolerance. Diabetes Obes Metab. (2017) 19:473-81. doi: 10.1111/dom.12854

51. Lalau JD, Al-Salameh A, Hadjadj S, Goronflot T, Wiernsperger N, Pichelin M, et al. Metformin use is associated with a reduced risk of mortality in patients with diabetes hospitalised for COVID-19. Diabetes Metab. (2020) 19:101216. doi: 10.1016/j.diabet.2020.101216

52. Lalau JD, Kajbaf F, Protti A, Christensen MM, De Broe ME, et al. Metforminassociated lactic acidosis (MALA): moving towards a new paradigm. Diabetes Obes Metab. (2017) 19:1502-12. doi: 10.1111/dom.12974

53. McCreight LJ, Bailey CJ, Pearson ER. Metformin, and the gastrointestinal tract. Diabetologia. (2016) 59:426-35. doi: 10.1007/s00125-0153844-9

54. Liu Q, Li S, Quan H, Li J. Vitamin B12 status in metformin treated patients: systematic review. PLoS ONE. (2014) 9:e100379. doi: 10.1371/journal.pone.0100379

55. Zhang Q, Li S, Li L, Li Q, Ren K, Sun X, et al. Metformin treatment and homocysteine: a systematic review and meta-analysis of randomized controlled trials. Nutrients. (2016) 8:798. doi: 10.3390/nu8120798

56. Tan J, Wang Y, Liu S, Shi Q, Zhou X, Zhou Y, et al. Long-acting metformin vs. Metformin immediate release in patients with type 2 diabetes: a systematic review. Front Pharmacol. (2021) 12:669814. doi: 10.3389/fphar.2021. 669814

57. Hoffmann M, Kleine-Weber H, Schroeder S, Krüger N, Herrler T, Erichsen $\mathrm{S}$, et al. SARS-CoV-2 cell entry depends on ACE2 and TMPRSS2 and is blocked by a clinically proven protease inhibitor. Cell. (2020) 181:271-80.e8. doi: 10.1016/j.cell.2020.02.052

58. Zhang J, Dong J, Martin M, He M, Gongol B, Marin TL, et al. AMPactivated protein kinase phosphorylation of angiotensin-converting enzyme 2 in endothelium mitigates pulmonary hypertension. Am J Respir Crit Care Med. (2018) 198:509-20. doi: 10.1164/rccm.201712-2570OC

59. Ursini F, Ciaffi J, Landini MP, Meliconi R. COVID-19, and diabetes: Is metformin a friend or foe? Diabetes Res Clin Pract. (2020) 164:108167. doi: 10.1016/j.diabres.2020.108167

60. Costela-Ruiz VJ, Illescas-Montes R, Puerta-Puerta JM, Ruiz C, Melguizo-Rodríguez L. SARS-CoV-2 infection: the role of cytokines in COVID-19 disease. Cytokine Growth Factor Rev. (2020) 54:62-75. doi: 10.1016/j.cytogfr.2020.06.001

61. Matsiukevich D, Piraino G, Lahni P, Hake PW, Wolfe V, O'Connor M, et al. Metformin ameliorates gender-and age-dependent hemodynamic instability and myocardial injury in murine hemorrhagic shock. Biochim Biophys Acta Mol Basis Dis. (2017) 1863:2680-91. doi: 10.1016/j.bbadis.2017.05.027

62. Park JW, Lee JH, Park YH, Park SJ, Cheon JH, Kim WH, et al. Sex-dependent difference in the effect of metformin on colorectal cancer-specific mortality of diabetic colorectal cancer patients. World J Gastroenterol. (2017) 23:5196-205. doi: 10.3748/wjg.v23.i28.5196

Conflict of Interest: The authors declare that the research was conducted in the absence of any commercial or financial relationships that could be construed as a potential conflict of interest.

Publisher's Note: All claims expressed in this article are solely those of the authors and do not necessarily represent those of their affiliated organizations, or those of the publisher, the editors and the reviewers. Any product that may be evaluated in this article, or claim that may be made by its manufacturer, is not guaranteed or endorsed by the publisher.

Copyright (c) 2021 Li, Yang, Yan, Sun, Zeng and Li. This is an open-access article distributed under the terms of the Creative Commons Attribution License (CC BY). The use, distribution or reproduction in other forums is permitted, provided the original author(s) and the copyright owner(s) are credited and that the original publication in this journal is cited, in accordance with accepted academic practice. No use, distribution or reproduction is permitted which does not comply with these terms. 